\title{
GEOLOGICAL EVOLUTION AND IGNEOUS ACTIVITY OF THAILAND AND ADJACENT AREAS
}

by

\author{
S. Suensilpong \\ C.K. Burton, N. Mantajit, and D.R. Workman
}

\begin{abstract}
The complex geological evolution of Southeast Asia poses various problems of mutual interest to all nations in the region. Many of these will be discussed at the forthcoming Third Regional Conference on Geology and Mineral Resources of Southeast Asia (III GEOSEA), scheduled for November 14-16, 1978 in Bangkok, Thailand. This review*, with its extensive list of references, gives an up-to-date outline of the geological evolution of Thailand in its regional setting and points to the geological phenomena currently being researched in the area.
\end{abstract}

Introduction

Thailand covers an area of about $518,000 \mathrm{~km}^{2}$, bounded to the west and north by Burma, by Laos to the north and east, by Cambodia to the east and by Malaysia to the south. Physiographically, the country can be divided into four distinct geographic regions: the mountainous highland in the north and northwest, the Khorat plateau in the northeast, the central Chao Phraya plain and the southern peninsula bounded by the Andaman and South China Seas (Fig. 1). The highest mountain, Doi Inthanon $(2,576 \mathrm{~m})$ is located in the northern highlands.

The present physiography of Southeast Asia is the result of a high level of tectonic activity, through Phanerozoic time at least. Igneous activity, evidently subdued initially, has
Fig. 1 .

GENERAL TECTONIC

FRAMEWORK OF

MAINLAND

SOUTHEAST ASIA

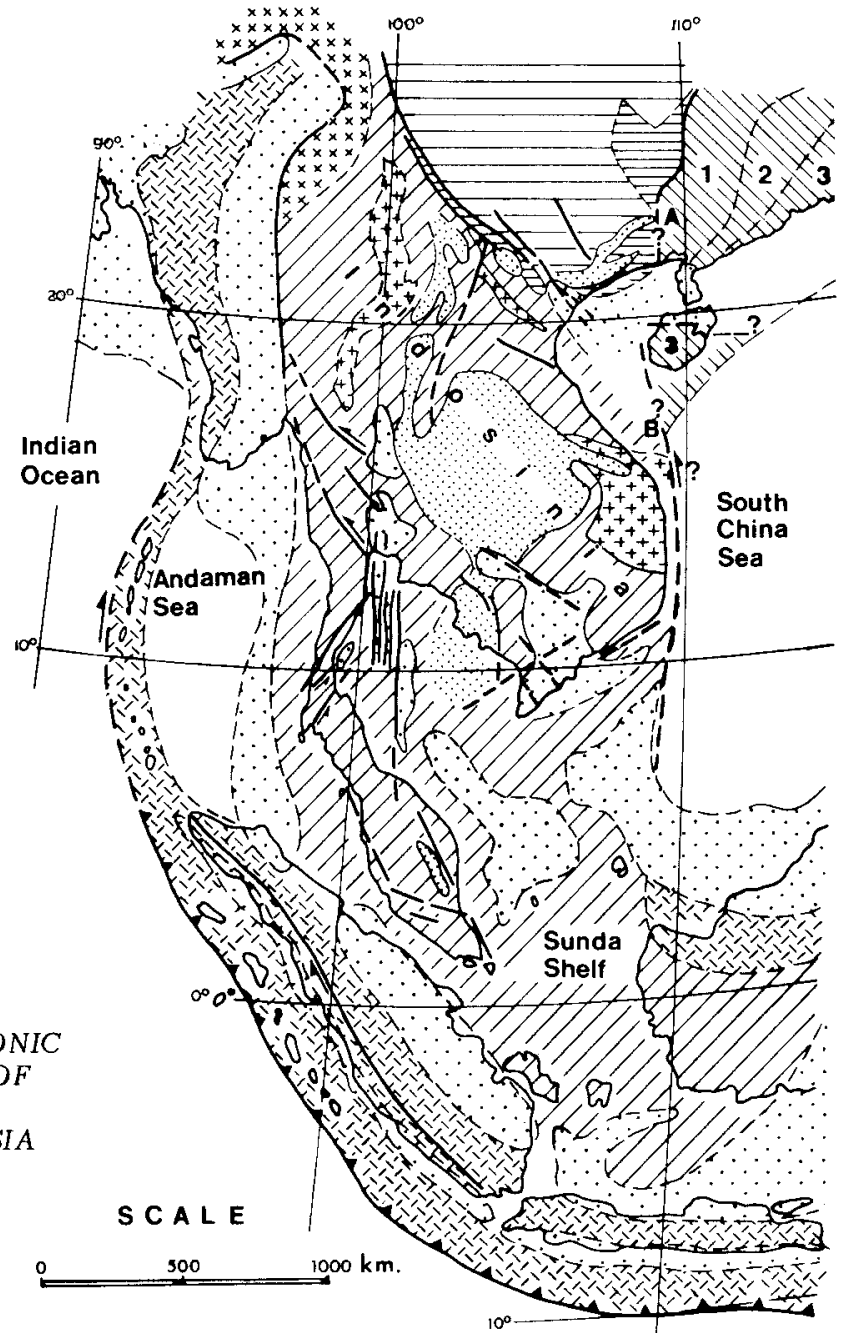

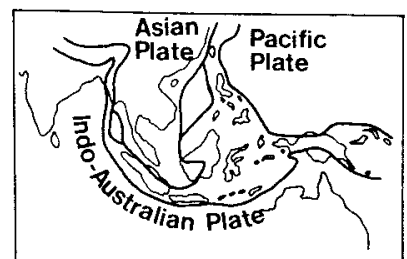

$x \times x$ Metamorphic and other rocks of the Himalaya fold system

Cainozoic sedimentary basins

Cretaceous-Cainozoic fold belts and volcanic arcs

Upper Mesozoic basins

(intra-continental)

Precambrian - Triassic marine strata (mainly Palaeozoic), in general strongorogenic igenous rocks

Main emergent areas or gean ticlines of Precambrian rocks within the Palaeozoic marine depositional terrain

South China platform (Palaeozoic platform cover on Precambrian basement

Activated margin of the South China platform

Southeast Asia tectogene (Palaeozoic folding, Jurassic - Cretaceous re-activation)

zone 1: Granites mainly Triassic

or older

zone 2 : Granites mainly Jurassic

tone 3 : Granites mainly Cretaceous

- 2 Principal faults known or inferred

Direction of relative and inferred actual transcurrent movement

Sources based on Hamilton (1972), Murphy (1975), Terman (1974) and wang et al. (1976) for information on China and Indonesia.

* Publication of this review was authorized by the Director-General, Department of Mineral Resources, Bangkok, Thailand. The Department is one of the co-organizers of III GEOSEA. 
played a more dominant role since the Upper Carboniferous. Kobayashi (1976) believed that the geological evolution of Thailand and its neighbouring countries could be classified into four constructive (sedimentation) and destructive (uplift, mountain building and erosion) stages.

In Southeast Asia, the great Alpine-Himalayan orogenic belt converges with that of the Circum-Pacific, producing a tripartite junction between the continental Asian plate to the north, the oceanic Pacific plate to the east and the IndoAustralian plate (partly oceanic and partly continental) to the west and south. This triple plate junction finds morphologic expression in the orogenic terrain of the Andaman, Indonesian and Philippine archipelagoes. Mainland Southeast Asia, as a promontory extending for some $2,500 \mathrm{~km}$ southwards from the main Asian continent, is located between the northwestern and northeastern branches of this convolute $\mathrm{Y}$-shaped plate junction (Fig. 1 inset).

Both the Alpine-Himalayan (Tethyan) and the CircumPacific orogens are long-standing and it is evident that Southeast Asia has been the site of plate junctions and geological complexity for some time. Burton (1970, 1972, 1974b) contends that the east Burma-west Thailand-Malayan orogenic belt, was formerly situated alongside the present Indian craton, from which it was separated in Mesozoic time by anti-clockwise rotational drifting as the Bay of Bengal was opened to form a sphenochasm.
The twin processes of orogenic evolution and cratonization have built up continental Southeast Asia from a small number of "microcontinents" or sialic rafts to form a stable mass, sometimes referred to as the Sunda Shelf or Sunda Shield (Hutchison, 1973a).

Our knowledge and understanding of the geology of Southeast Asia has greatly improved during the last decade. The concept of plate tectonics has been applied by many geoscientists to delineate its geological development (Katili, 1973; Hamilton, 1973; Murphy, 1975). Some have also tried to correlate the genesis of the region's ore deposits with plate theory (Mitchell \& Garson, 1972, 1976; Mitchell, 1973; Katili, 1973; Rona \& Neuman, 1976; Suensilpong, 1977a). Whether the information currently at hand is sufficient to explain the entire geological evolution of the region on this basis is debatable. The hypothesis, however, can be more easily applied to interpret the younger stages of geological development, for which more data are available.

The stratigraphic sequences and geological events recorded in Thailand are summarized in Table 1.

\section{Precambrian to Tertiary development}

From the early Paleozoic to early Mesozoic, the region was extensively covered by sea and may be regarded as the eastern part of the Tethyan marine realm. Areas which might have emerged during Paleozoic to early Mesozoic time

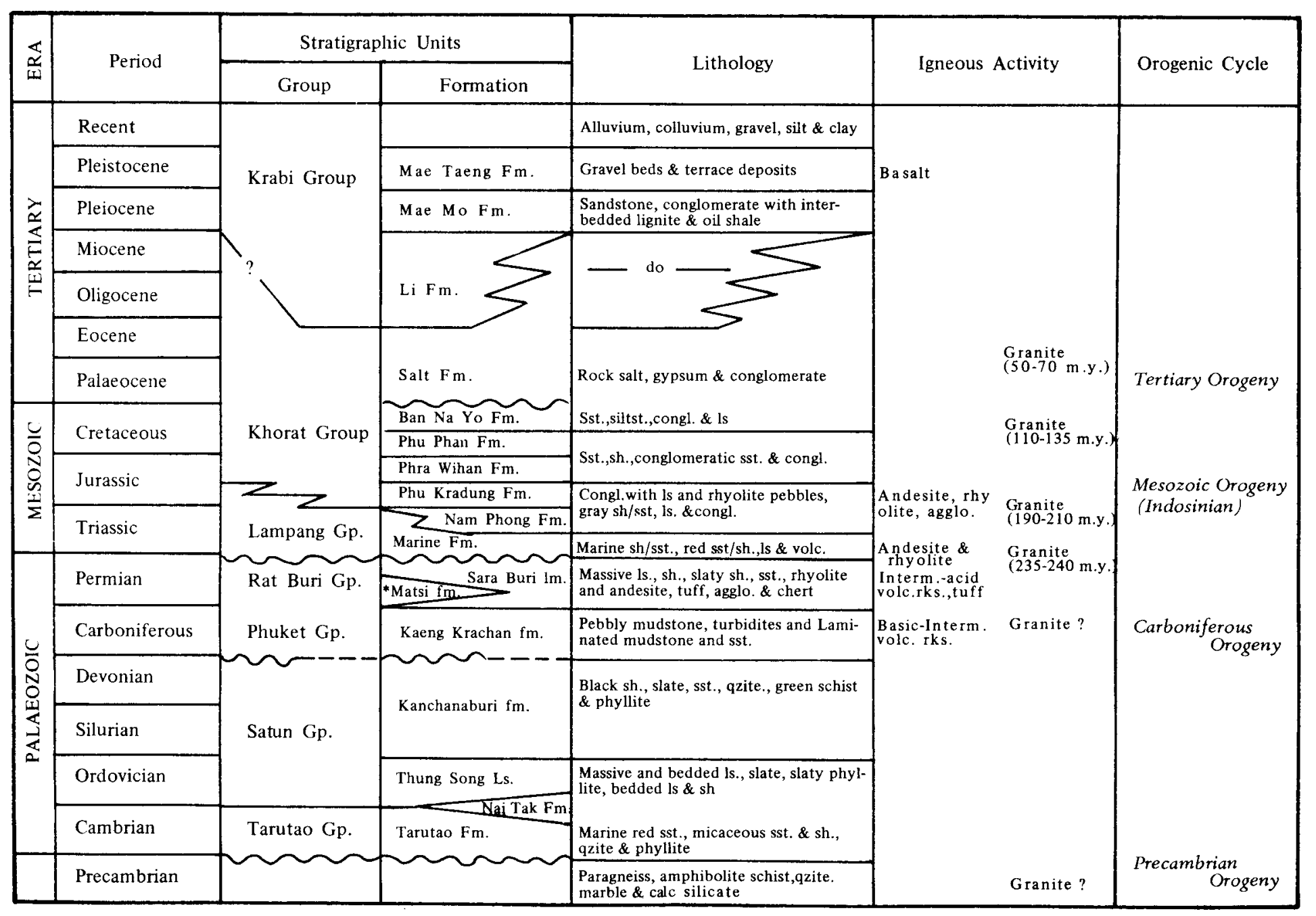

Table 1. SUMMARY OF GEOLOGICAL EVOLUTION OF THAILAND

* New stratigraphic formation proposed by 
were relatively short-lived and/or small.

\section{Precambrian}

The oldest stratigraphic unit recognized in Thailand is a group of folded and contorted gneisses with calcareous and clastic metasediments of amphibolite facies, regarded as Precambrian in age. No radiometric dates are yet available to confirm the age assignment, which is based both on the nature of the rocks and on field relationships with the overlying Cambro-Ordovician formations (the contact being usually unconformable).

This inferred Precambrian occurs mainly in the western part of the country, where scattered outcrops extend in a NS alignment (such as NW and SW of Chiang Mai). Along the Tak-Mae Sot highway, presumed Precambrian paragneisses and associated plutonic rocks of granite or granodiorite composition are strongly sheared and faulted. The estimated thickness is about $3.5 \mathrm{~km}$ (Campbell, 1975).

Some geologists have proposed that orthogneiss in paragneiss located further south (west of Uthaithani, near Kanchanaburi and south of Hua $\mathrm{Hin}$ ) should also be included in the Precambrian. Field evidence has shown that this granite gneiss is much younger. In fact, recent dating of or thogneiss at Cha-am, Petchaburi, from the pluton that continues to the north of Hau Hin, gives a whole rock age of 240 Ma (Early Triassic) by the $\mathrm{Rb} / \mathrm{Sr}$ method (Beckinsale, personal communication).

\section{Paleozoic}

The sedimentary sequences indicate a long history of deposition from Cambrian to Early Carboniferous. An elongated trough extends from west Yunnan in China and the Shan States of Burma, passing south through Thailand to the Thai-Malay peninsula (Kobayashi, 1964, 1973). There was apparently limited igneous activity during this time.

\section{Cambrian}

The rather mature, cross-bedded sandstone at Tarutao Island in southern Thailand includes the Upper Cambrian trilobites Pagodia and Saukiella. This rock unit extends into Langkawi Island and Malaysia and may be correlated with the Moelone-hein Group of the Pindaya Range in Southern Shan States (Maung Thein, 1973) and west Yunnan. The coarse cross-bedding of the Tarutao formation points to shallowwater origin. It has been suggested that the source of the clastic sediments may be from a Precambrian shield to the west (Burton 1967, 1972). Some Cambrian strata in northern Thailand are weakly metamorphosed.

\section{Ordovician}

Following the Upper Cambrian with apparent conformity is a development of impure carbonate rocks dominated by the Thung Song Limestone and probably extending from Lower Ordovician to Lower Devonian in the southern part of the country (Brown et al., 1951; Burton, 1974a). In the north, Ordovician strata are found to the east of Mae Sariang, where the succession includes siltstone and sandstone intercalated with dolomitic limestone. Middle to Upper Ordovician fauna are recorded. An Ordovician sequence is also found to the West of Kanchanaburi in west Thailand.

\section{Silurian to Carboniferous}

In the Silurian to Carboniferous sedimentary rocks of the Yunnan-Malayan orogen, "miogeosynclinal" and "eugeosynclinal" facies can be recognized to the west and east respectively. The succession is largely argillaceous, with immature arenites becoming prominent high in the succession accompanied by minor carbonates. In the eastern belt these rock types are augmented by volcanic tuff along with an ophiolite suite.

The argillite with arenite (greywacke) form a turbidite (flysch) sequence of approximately Lower Carboniferous age which is well developed in peninsular Thailand and the adjacent parts of Burma and Malaysia. This includes granite clasts recently dated as Precambrian (see below). The incidence of flysch implies contemporary orogeny, confirmed by the absence of Late Carboniferous rocks over much of the region. In some localities (for example, Prachuab Khirikhan and Chumphon in Thailand, Kedah in Malaysia) there appears to be a continuous succession from the Lower Carboniferous turbidites through a suite of shales, with more mature arenites becoming somewhat calcareous as it passes up into the Permian.

\section{Permian}

In Thailand and its neighbouring areas, the Permian is predominantly represented by a thick limestone sequence (Ratburi Group) with the type area of the limestone at Saraburi, NE of Bangkok. The stratigraphy and paleontology of the "Saraburi limestone" (often referred to as "Ratburi limestone") has been well documented (Kobayashi 1964, Bunopas, 1976, Waterhouse and Piyasin, 1970). The index fossils of this succession are fusulinids (Pitakpaivan, 1965), and brachiopods (Waterhouse and Piyasin, 1970; Grant, 1976). Besides the calcareous rocks, the Permian includes prominant arenaceous rocks and some chert in the peninsula, and andesite, rhyolite and tuff in the east of northern Thailand. Apparently the eugeosynclinal and miogeosynclinal sectors as indicated in the Devonian (Bunopas, 1976) persisted after the Carboniferous orogeny.

\section{Triassic to Cretaceous}

While there may have been a break in the succession late in the Permian (except in nor th Malaysia), sedimentation was vigorously renewed in the Middle and Late Triassic, largely of turbidite facies again, with minor limestone plus volcanic tuff and volcanic agglomerate in the eastern zone. These rocks are often very fossiliferous; Halobia, Daonella and Posidonia together with ammonites are commonly found. The Triassic rocks of north Thailand have been termed the Lampang Group and have been subdivided into several formations by Piyasin (1972). The Lampang Group is also represented in the peninsula and correlatives of the same lithofacies are found in Malaysia and Burma.

The tectonic activity represented in the flysch facies culminated toward the end of the Triassic period in intensive and extensive folding throughout the region ascribed to the Indosinian. Orogeny (Workman, 1975, 1977). Emplacement of huge granitic batholiths was associated with this tectonic event. The whole of continental Southeast Asia was uplifted, forming large inland molasse basins beginning in about Carnian time. The largest of these, the Khorat basin of NE Thailand, which extends into Cambodia, Laos and South Vietnam, is thought to have been a great inland sea possessing intermittent links with the open sea in the SE. Continentalparalic conditions prevailed in the Khorat basin from early Jurassic to the Upper Cretaceous, resulting in over $4,000 \mathrm{~m}$ of red beds known as Khorat Group (Ward and Bunnag, 1964; Iwai, et al., 1966).

Continuous shallow sea sedimentation evidently took place during Triassic to Jurassic NW and west of Sri Sawat, Kanchanaburi (Kemper, et al., 1976) where carbonates accumulated. By Middle Jurassic time, the whole area, shown in Fig. 1 as "Indosinia", together with "Sundaland" to the south, was continental.

It was probably in the Late Cretaceous-Early Tertiary, subsequent to the emplacement of Middle Cretaceous granite, that another phase of regional tectonic activity took place. This resulted in the uplift of the "old" Khorat basin to form the Khorat Plateau, within which continental deposits including evaporite were subsequently deposited.

Three layers of salt beds separated by claystone are recognized in the evaporite formation. The thickness of this salt unit varies up to a maximum of $434 \mathrm{~m}$. Drilling in the uppermost part of the lower salt bed led to the discovery of a section rich in potash. The mineralogy of potash minerals is simple, consisting predominantly of carnallite, halite and tachyhydrite, with a minor amount of sylvite at the top of the section (Japakasetr, 1977). 
Orogenic cycles and timing of igneous activity

Current geological information suggests there may have been five tectonic-plutonic episodes in Thailand and adjacent areas: Precambrian, Middle-Late Carboniferous, Late Permian-Early Triassic, Late Triassic-Lower Jurassic, Late Cretaceous-Early Tertiary. The distribution of igneous rocks is summarized in Fig. 2.

\section{Precambrian Orogeny}

Evidence of Precambrian orogenic movements is sparse. It includes the folds and metamorphism of the lower sequence of the inferred Precambrian clastic rocks (Baum et al., 1970).
In Burma, the tightly folded and metamorphosed nature of the rocks of the Chaung Magyi Series is believed to have resulted from the late Precambrian Charnian orogeny (Maung Thein, 1973).

Igneous rocks which might have been associated with a Precambrian orogenic episode were first noted by von Braun (1969). Radiometric dating recently carried out on a boulder of trondhjemite in the Carboniferous mudstone of the Singa formation at Pulau Tepor off NW Malaysia, indicates the existence of Precambrian plutonic activity in regions which are, at least now, nearby (Stauffer and Snelling, 1977). This is the oldest plutonic rock yet recorded in Malaysia. A

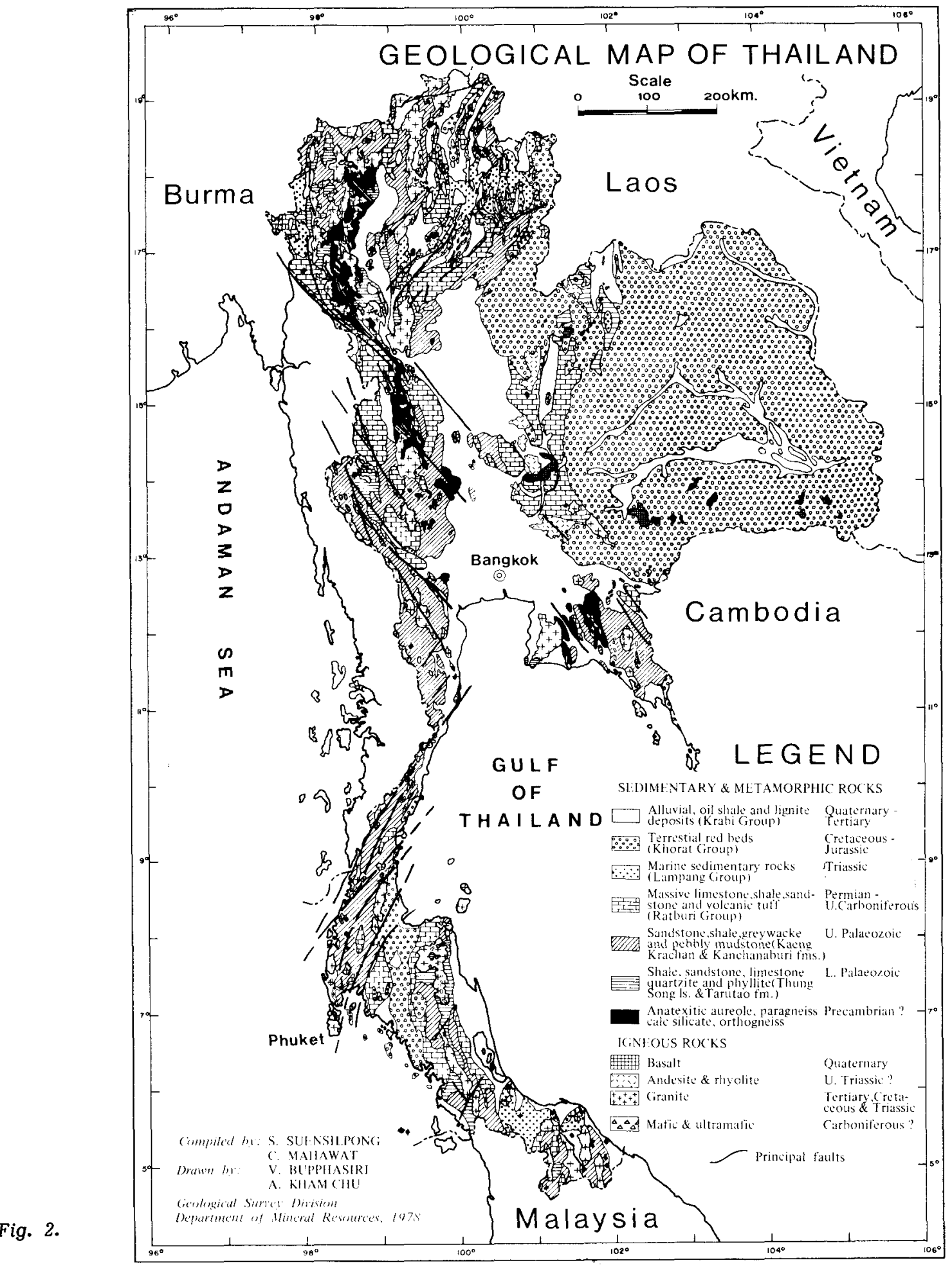


similar type of Carboniferous conglomeratic mudstone or greywacke in south Thailand (Phukct Group) also contains granite clasts up to $60 \mathrm{~cm}$ in diameter, and $\mathrm{jt}$ was suggested by Klompe (1962) that this granite too might be of Precambrian origin.

\section{Lower Paleozoic}

Within the Lower Paleozoic succession there are some volcanic members in the eugeosynclinal sequence but there is no record of plutonic activitv.

\section{Carboniferous Orogeny}

This orogenic event apparently involved large scale thrusting in northern Thailand (Baum et.al., 1970) and in eastern Laos and north-central Vietnam (Fromaget, 1941). The syn-orogenic sandstone containing reworked fragments of older strata is possibly a result of these movements (Baum et al., 1970). There does not seem to have been any prolonged or extensive regional emergence as a result of these Early Carboniferous movements, judging by the apparent completeness of the Carboniferous succession reported from some areas (see above).

Igneous activity is represented mainly by volcanic eruptives in the eugeosynclinal sertor. There is limited evidence for Carboniferous plutonism in Thalland. Only two granites have been identified as being of possible Carboniferous age, one with an age of $307 \pm 18 \mathrm{Ma}$ at La-un, Ranong, and the other $272 \pm 14 \mathrm{Ma}$ at Khao Taphao Kham (Burton \& Bignell, 1969). Baum et al. (1970) proposed, on the basis of one sample, that the granite along the LampangLamphun highway was of Carboniferous agc (Rb/Sr whole rock age of $344 \mathrm{Ma}$ ) but a more detailed investigation by Teggin (1975) now suggests that it is Upper Triassic (206 \pm $4 \mathrm{Ma}, \mathrm{Rb} / \mathrm{Sr}$ whole rock). Carboniferous granite $(280 \mathrm{Ma})$ is also reported from West Malaysia (Hutchison, 1973b).

Volcanic activity in the Permian is restricted to volcanic tuff and breccia in northern Thailand and in east peninsular Malaysia.

\section{Early Mesozoic}

The Indosinian orogeny which may span the Late Permian to Early Jurassic according to Workman $(1975,1977)$, is marked by an unconformity between the Permian and the Triassic in north Thailand (Piyasin, 1972) and, in places where the marine Triassic beds are missing, between the Permian and red beds of the Khorat Group. Ir the Lower Triassic prior to the deposition of Middle to Upper Triassic flysch, granite emplacement was widespread in Thailand (c.g. North Thailand, von Braun, et al., 1977) and elsewhere in SE Asia, such as Malaysia, North Vietnam, NE Cambodia and Laos (Workman, 1977).

Nevertheless, the majority of the radiometric age determinations which have been made on the Indosinian granites yield Upper Triassic dates (e.g. the Khuntan and Mae Sariang batholiths in the north, the granite SW of Prachuap Khirikhan peninsula and the Main Range, and the satellite batholiths of West Malaysia). It seems likely that the granite gneisses of Tenasserim and along the western margin of the Shan Plateau in Burma may be of the same age, although, based on stratigraphic evidence, they have been postulated to be Kimmeridgian (Late Jurassic) by Maung Thein (1973). Tin mineralization in part of the Upper Triassic Khuntan Batholith appears related to a late tourmaline-bearing granite (Suensilpong, et al., 1977).

Volcanic rocks of possible Upper Triassic - Lower Jurassic age form a belt of rhyolite and andesite extending from west of Luang Prabang through Pak Lay in Laos into Loei in Thailand, via Petchabun, east of Lopburi and Saraburi and continuing to Ko Chang in the eastern part of the Gulf of Thailand. The age assignment is based on these eruptive rocks intruding the joint planes of the Upper Triassic granite. In addition, pebbles of similar andesite and rhyolite are found in the lowest beds of the Khorat Group (late Triassic to late Cretaceous).

\section{Cretaceous}

In the mid-Cretaceous, further emplacement of granite occurred in the Phuket-Ranong area of south Thailand (Garson et al., 1975) and elsewhere in southern and western Thailand. In northern Thailand, the only igneous rock thus far dated as Cretaceous is the Mae Lama granite SW of Chiangmai (130 Ma, Rb/Sr whole rock, Beckinsale, personal communication). Klompe (1962) also reported a midCretaceous granite in Central Sumatra $(112 \pm 25 \mathrm{Ma}, \mathrm{Rb} / \mathrm{Sr})$.

Cretaccous activity has been reported from other adjacent regions. In Burma, the granite at Yinmabin (the inferred northern continuation of the Tenasserim granite) is interpreted as Cretaceous (Maung Thein, 1973). Although a few $\mathrm{K} / \mathrm{Ar}$ Cretaceous dates have been obtained from Malaysia, there is little proof of mid-Cretaceous granite, aside from a pink granite at Johore with an age of $108 \pm 60 \mathrm{Ma}$ (Hutchison, 1973b).

Cretaceous granite is considered to be important for tin mineralization in south Thailand (Garson et al., 1975) and in Malaysia (Burton, 1972). Suensilpong (1977b), however, suggests that granites of various ages may be related to tin mineralization in the southeast Asian tin belt.

\section{Late Cretaceous - Early Tertiary}

According to Suensilpong (but not his co-authors), the Late Cretaceous - Early Tertiary movements caused the folding and uplift in rocks of the Khorat Group (on the Khorat Platcau as well as Ko Yao Yai in the peninsula), and the deformation pattern found in the Triassic and Cretaceous granites in Thailand, extending from Tak to Phuket, and exhibiting the reorientation of mineral grains along NW-SE lines (Suensilpong, 1977a). The discordant radiometric ages of the granites (most Triassic and Cretaceous granites give $\mathrm{K} / \mathrm{Ar}$ ages between 50-70 $\mathrm{Ma}$ ) is another phenomenon which could be linked to this tectonic activity. Similarly, discordant ( $\mathrm{Rb} / \mathrm{Sr}$ and $\mathrm{K} / \mathrm{Ar}$ ) ages in Malaysia may also have resulted from Early Tertiary deformation. For example, the biotite granite at Western Road, Penang Island gives a whole rock $\mathrm{Rb} / \mathrm{Sr}$ age of $197 \pm 10 \mathrm{Ma}$, but the $\mathrm{K} / \mathrm{Ar}$ age on biotite is only $67 \pm 4 \mathrm{Ma}$ (Hutchison, 1973b).

The regional deformation is thought to be a result of the collision of plates and subduction which took place in the Early Tertiary (Suensilpong, 1977a). Curray and Moore (1974) proposed that the initial contact or collision between the Indian plate and the Eurasian plate took place in Late Paleocene time, or approximately $55 \mathrm{Ma}$ ago, and led to the Indian plate underthrusting the Eurasian plate (the idea was proposed earlier by Le Pichon, in Paul and Lian, 1975, and by Sclater and Fisher, 1974). The collision zone strikes in a NWSE direction conforming to the regional deformation pattern found on the continental side.

The emplacement of most of the Tertiary granite probably took place during a late stage of tectonic activity in the Paleocene or early Eocene. The morphology of the intrusives (dikes, stocks, or plutons within pre-existing granites) indicates high-level, post-orogenic emplacement. The rock lacks a foliation or lineation common in Mesozoic granites. This granite, referred to as leucogranite or 'Haad Sompan type' granite (Arayakanon 1961), is believed to be the most important granite phase linked to tin mineralization (Suensilpong, 1977a). Suensilpong proposed that it may have been generated within the earth's crust as postulated by Taylor (1974), resulting in the partial melting of crustal rocks, including some pre-existing granites, above a subduction zone. Tin, presumably derived from the sediments and pre-existing granites, became enriched in the new granite melt. The chemical composition of the newly formed granite (relatively high $\mathrm{SiO}_{2}, \mathrm{Al}_{2} \mathrm{O}_{3}$ and low $\mathrm{Na}_{2} \mathrm{O}$ ) indicates that it is an S-type (Chappell and White, 1974), which supposedly signifies derivation from sedimentary rocks.

Most Tertiary granites are in the tin mining area ir south Thailand, such as Phuket (Garson, et al., 1975). Ir 
northern Thailand, Tertiary granites occur at Samoeng (Teggin, 1975), west of Payao and southeast of Sa (von Braun, 1969).

\section{Post-Paleocene to present}

Post-Paleocene history is marked by the replacement of the earlier compressional regime by a tensional one in Oligocene-Quaternary. Numerous narrow graben opened both on land and offshore and were rapidly filled with sediments. For example, the Gulf of Thailand consists of a series of N-S elongate horsts, grabens and basins filled with thick Tertiary sediments of Oligocene - Quaternary age and up to $9,000 \mathrm{~m}$ thick in the deepest part of Malay basin (Achalabhuti, 1976; Woollands and Haw, 1976). Interdigitation of continental, paralic and marine facies was detected in drilling. Natural gas deposits in commerical amounts and oil occurrences were discovered in Tertiary sandstone within these sequences (Achalabhuti, 1976).

On land, the most striking graben is the Red River rift in north Vietnam - about $250 \mathrm{~km}$ long and infilled with up to $1,000 \mathrm{~m}$ of Cenozoic sediments. The Chao Phraya Basin of central Thailand is also believed to be a graben. Other Tertiary basins in the region contain lignite or oil-shale deposits such as the Fang (Oligocene), Li (Oligocene), Mae Moh (Pliocene) and Mae Sot (Pliocene-Pleistocene) basins (Buravas, 1975).
Starting probably at about the Miocene and culminating in the late Pliocene and Pleistocene, basalt erupted in many locations in Thailand, South Vietnam, Cambodia and Malaysia. These lavas include alkaline types such as basanites and limburgites. Some basalts in Thailand and Cambodia bear commercial quality sapphires and rubies. Volcanic activity inland ceased, apparently about 600,000 years ago in the early Upper Pleistocene. Offshore, however, some eruptions have occurred in historical times, the latest being the temporary appearance of a new island off the coast of Vietnam near Poulo Ceciv in 1923.

\section{Conclusion}

Because of the complexity of this region, it is not easy to summarize coherently its geological evolution. However, Thailand, Burma, Malaysia and Indochina possess so many geological similarities, that it is difficult to consider this part of Southeast Asia as other than a single crustal segment during Phanerozoic time. It certainly did not exist as one cohesive unit for any appreciable period of time before the late Triassic. The processes related to the movement of this plate relative to its neighbours (and their possible scientific and economic implications) will certainly be a topic of more intensive research in the future.

\section{REFERENCES}

Achalabhuti, C., 1976, Petroleum geology of Thailand (Gulf of Thailand and Andaman Sea), Summary, in Halbouty, M.T., Maher, J.C. and Lian, H.M. (eds.), Circum-Pacific Energy and Mineral Resources: Am. Assoc. Pet. Geol., Mem. 25, p. 251-255.

Aranyakanon, P. [96], The cassiterite deposit of Haad Som Pan, Ranong Province, Thailand: Report of Investigation No. 4, Dept. Min. Res. Bangkok, Thailand.

Baum, F., Braun, E. von. Hahn, L., Hess, A., Koch, K.E., Kruse, G., Quarch, H. \& Siebenhuner, M., 1970 On the geology Quarch, H. \& Siland: Beih. geol. Jb. Heft 102,23 .

Braun, E. von, 1969, The age of granites in northern Thailand: A Second Tech. Conf. on Tin Bangkok, Thailand, v. 1, p. 15]-157. The International Tin Council, London.

Braun, E. von. Besang, C., Eberle, W., Harre, w. Kreuzer, H., Lenz, H., Muller, P. \& Wendt, I., 1976. Radiometric age determinations of granite in northern Thailand: Geol. Jb. Heft 21, p. 171-204.

Brown, C.F., Buravas, S., Charaljavanaphet, J., Jalichandra, $N$ Johnston, W.D. Sresthaputra, $v$. Jalichandra, N., Johnston, W.D., Sresthaputra, V. \& Taylor, G.C., 1951, Geological reconnaissance of the minera

Bunopes, S, 1976, Stratigraphic surcessions in Thailand - A Preliminary 5ummary: I. Geol. Sor Thailand, v. 2, No. 1-2, p. $31-58$.

Buravas, S., 1975 , Age of the Mae Soon oil field of Fang basin, Chiang Mai province: Proceedings of the conference on the Geology of Thailand, Chiang Mai University, Special publication No. 1, v. 2, p. 61-65.

Burton, C.K., 1967. The Mahang Formation: a mid-Palaeozoic euxinic facies from Malaya - with notes on its conditions of deposition and paleogeography: Geol. Mijnbouw, v. 46, p. 167-187. 1970, The palaeotectonic status of the Malay Peninsula: Palaeogeogr. Palaeorlimatol. Palaeoecol., v. 7 , p. 5160.

1972 , Outline of the geological

evolution of Malaya: 7. Geol., v. 80, p. 293-309. 1974 , The

Formation and Thung Song Limestone) of peninsular Formation and Thung Song Limestone) of pen!nsular Thailand

, 1974b, Penjnsular Thatand in A.M. Spencer, (ed.), Mesozoic-Cenozoic orogenic belts: Geol. Soc. Lond., Spec. Publ. 4 p. $301-315$

Burton, C.K. \& Bignell, J.D., 1969, CretaccousTertiary events in SE Asia: Geol. Soc. Am., Bull., 80 , p. 681-688.

Campbell, K. V., 1975, Metamorphic and deformational events recorded in the Lan Sang gneiss:
Proceedings of the conference on the geology of Thailand, Chiang Mai University. Special publication No. 1, v. 2, p. 15-23.

Chappell, R.W. \& white, A.J.R., 1974, Two contrasting granite types: Pacific Geology, v. 8, p. $173-174$.

Curray, J.R. \& Moore, D.G., 1974, Sedimentary and tectonic processes in the Rengal deep-sea fan and geosyncline, in Burk, C.A. (ed.), The geology of geosyncline, in Burk, C.A. led.), The geology of

Fromatinental margins: Springer-Verlag, p. romaget, J., 19:1 L'Indochine Française, sa
stricture géologioue, ses roches, ses mines et leur structure géologique, ses roches, ses mines et leur relations possible avec la tertonique:

Garson, M.S Young, B. Mitchell, A.H.G.. \& Tait A.B.R., 1975, The geology of the tin belt in Peninsular Thailand, around Phuket, Phanggna and Takua Pa: Overseas Mem. I, Inst. Geol. Sci. London, $112 \mathrm{p}$.

Permian Brachiopocis from Southern Thailand: J. Paleontol, v. 50 , No. 3, P. 1-269.

Hamilton, W. 1973, Tectonics of the Indonesian region: in Tan, B.K. (ed.). Proccedings, regional region: In Tan, B.K. (ed.). Proccedings, regional Soc Malaysia, Bull. No. 6, p. 3-10.

Hutchison, C.S. 1973a, Tectonic evolution of Sundaland: in Tan, B.K. (ed.), Proceedings, reginna! conference Soc. Malaysia Bulf. 6., p. 61-86. $1973 \mathrm{~b}$, Plutonic artivity, in Gobbett D.J. \& Hutchison, C.5. (eds.), Geology of the Mala Peninsula: West Malaysia and Singapore Wiley-Interscience, p. 215-252.

Iwai, J., Asama, K., Veeraburus, M. \& Hongnusonthi, A., 1966, Stratigraphy of the so-called Khorat Series and a note on the fossil plant-bearing Palaeozoic strata in Thailand: Jap. J. Geol. Geogr., v. 37, No. 1, p. $21-38$

Japakasetr, T., 1977, Potash investigation in northeastern Thailand: Dept. of Min. Res. Publication, Bangkok, Thailand, $26 \mathrm{p}$.

Katili, 7.A., 1973, Plate tectonics and its significance in the search for mincral deposits in western Indonesia: Ccop Technical Bull., v. 78. p. 23-27.

Kemper, E. Maronde, H.D. \& Stoppel, D., 1976 Triassic and Jurassir in the region northwest and west of Sri Sawat (Kanchanaburi Province Western Thailand): Geol. Jb., Heft 21, p. 93-127.

Klompe, Th. H.F., 1962, Igneous and structura features of Thailand, Geol. Mijnibouw, v. 41, p. $290-302$.

Kobayashi, T., 1964 Geology of Thailand, in Kobayashi, T. \& Toriyama R., (eds.), Geology and
Palaeontology of Southeast Asja: Univ. of Tokyo Press, ४. 1, p. 17-29. 1973, The carly stage of the Burmese-Malayan geosyncline, in Tan, B.K. (ed.), Proceedings, regional conference on the geology in Southeast Asia, Geol. Soc. Malaysia, Bull. 6, P. $119-129$.

1976, Prata Samutopatam toward d's palaeontology: iour ages of her geological history.

Maung Thein, 1973, A prefiminary synthesis of the aung Thein, 1973, A prefiminary synthesis of the geological evolution of Burma with reference to the (ed.). Proceedings, regional conference on the geology (ed.), Proceedings, regional conference on the geology of Southe
$87-116$.

Mitchell, A.H.G., 1973 Metallogenic belts and angle of dip of Benioff zones: Nature, v. 245 , p. $49-52$ 1976. Southeast Asia tin granites: Magmatism and mineralization in subduction and collision related setting: CCOP Newsletter, Bangkok, v. 3, p. $10-14$

Mitchell, A.H.G. \& Garson, M.S., 1972, Relation of porphyry copper and Circum-Pacific tin deposits to palaeo-Benioff zones: Inst. Min. Metall. Trans., Sect. B., v. 81, p. B $10-\mathrm{B} 25$. 1976. Mineralization at plate boundaries: Min. Sci. Eng., v. 8, No. 2, p. 129-169.

Murphy, R.W., 1975, Tertiary basins of Southeast phy, R.W., 1975, Tertiary basins of Southeast
Asia: SEAPEX proceedings, v. II, p. 1-36.

Asia: SEAPEX Proceedings, v. ll, p. 1-36. basins of Southeast Asia, Bay of Bengal to South China Sea: World Pet. Congr., Proc., No. 9, v. 3, p. $107-121$.

Pitakpaivan, K., 1965, The fusilinacean fossils of Thailand, pt. I, in Fusulines of the Rat Buri limestone of Thailand: Mem. Fac. Sci. Kyushu Univ., Ser. D, v 17 , p. $1-69$

Piyasin, S., 1972, Geology of Lampang Sheet, NE 47-7; srale 1:250,000; Report of Investigation No. 14. Dept, Min. Res., Bangkok, Thailand.

Rona, P.A. \& Neuman L.D., 1976, Plate tectonics and minera! resources of the Circum-Pacific region, in Halbouty, M.T., Maher, J.C. and Lian, H.M.(eds.), Circum-Pacific Energy and Mineral Resources: Am. Assoc. Pet. Geol., Mem. 25, p. 48-57.

Sclater, J.G. \& Fisher, R.L. 1974 Evolution of the east central Indian Ocean, with emphasis on the tectonic setting of the Ninetyeast Ridge: Gieol. Soc. tectonic setting of the Ninetyea
Am., Bull. v. 85 , p. 683-702.

5tauffer, P.H. \& Snelling. N.J., 1977, A Precambrian tronchiemite boulder in Palaeozoic mudstone of NW Malaya: Geol. Mag., v. 114 (6). p. $479-482$. 
Suensilpong, S., 1977a, The role of plate collision in tin mineralization in Thailand: Paper presented at th Circum-Pacific

Toyama, Japan.

Seunsilpong, S., 1977b, The possible age of tin mineralization in Thailand: 3rd International Tin Symposium, La Paz, Bolivia, 8 p.

Suensilpong, S., Meesook, A. Nakapadungrat, S. \& Putthapiban, P. 1977, The granitic rocks and mineralization at the Khuntan Batholith, Lampang: Geol. Soc Malaysia, Bul. 9 P. 159-173.

Taylor, D., 1974, The liberation of minor elements from rocks during plutonic igneous cycles and subsequent concentration to form workable ores, withWaterhouse, J.B. \& Piyasin, S., 1970, Mid-Permian particular reference to copper and tin: Geol. Soc. Malaysia, Bull. 7, p. 1-16.

Teggin, D.E., 1975, The granites of northern Thailand: Unpublished Ph.D. Thesis, Manchester University, U.K.

Terman, M.J. (ed.), 1974, Tectonic Map of China and Mongolia (2 sheets): Geol. Soc. Am.

Ward, D.E. \& Bunnag D., 1964, Stratigraphy of the Mesozoic Khorat Groups in northeastern Thailand: Report of Investigation No. 6, Dept. Min. Res., Bangkok, Thailand, 95 p.
Brachiopods from Khao Phrik, Thailand:

Woollands, M. A Haw, D. 1976 , Tertiary stratigraphy and sedimentation in the Gulf of Thailand: SEAPEX Program, Offshore South East Asia Conference, Paper 7, 22 p.

Indochina, 3. Geol. Soc. Thailand, v, 1, No, 1-2, p. $3-19$.

, 1977, Geology of Laos, Cambodia, South Vietnam and the eastern part of Thailand: Overseas Geol. \& Miner. Resour., No. 50, 33 p.
Workman, D.R., 1975, Tectonic Evolution of

\section{ABOUT THE AUTHORS:}

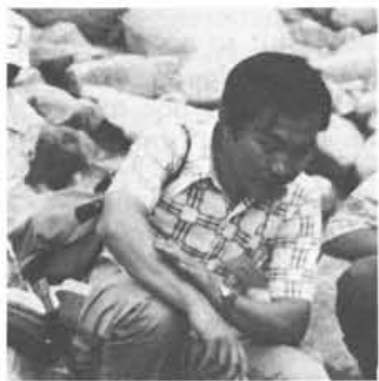

S. Suensilpong
$* * * * * * * * * * * * * *$

N. Mantajit

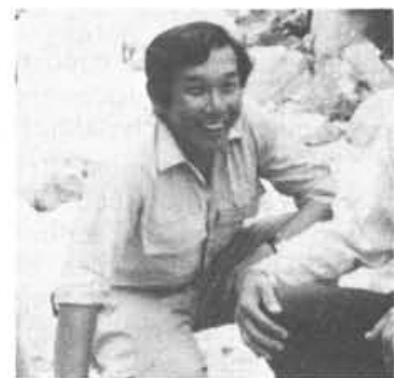

N. Mantajit is a senior geologist with the Geological Survey, Department of Mineral Resources, Thailand, and geologist-in-charge of the Department's geological survey party studying igneous and isotope geology in Southern Thailand.

EDITOR'S NOTE: Topics scheduled for discussion at the forthcoming III GEOSEA pertain to regional geology, structural geology and tectonics, stratigraphy and sedimentology, igneous and metamorphic petrology, paleontology and biostratigraphy, marine geology, mineral deposits, fossil fuels, geochronology, hydrogeology, geochemistry, quaternary geology, engineering geology and geotechnics.

IUGS participation in III GEOSEA includes

- an educational seminar on data management in geosciences, sponsored by COGEODATA and IGCP Project 98: Standards for computer applications in resource studies;

- a session on technology transfer in developing countries, organized by IUGS, in cooperation with AGID, for the UNESCO-sponsored Regional Network for Geosciences in Southeast Asia;

- regional meetings of IGCP Project 32 (Stratigraphic correlations between sedimentary basins in the ESCAP region) and Project 30 (Circum Pacific plutonism);

- a full-day meeting of representatives from IGCP national committees and working groups;

- short meetings related to activities of IGCP Project 26 (Mineralization associated with acid magmatism), Project 98 (Standards for computer applications in resource studies) and Project 156 (Phosphorites of the Proterozoic-Cambrian);

D.R. Workman

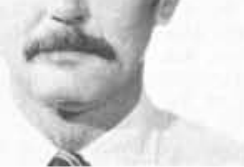

- meetings pertaining to thematic maps on geology of Southeast Asia, organized by CGMW (an affiliated association).

Requests for information on the Conference

Formerly a senior geologist with the Institute of Geological Sciences, London, England and a mineral adviser to the Economic and Social Division, Mekong Project Secretariat, ESCAP, David R. Workman is now the Economic Affairs Officer, Mineral Resources Section, Natural Resources Division, ESCAP. should be directed to Conference Secretary, III GEOSEA, Division of Geotechnical and

Transportation Engineering, Asian Institute of Technology, P.O. Box 2754, Bangkok, Thailand. 